\title{
Productive and reproductive performance of Saanen goat at AZ-Zahra farm of Sandakan in Malaysia
}

\author{
MAMY Khandoker ${ }^{1 *}$, N Afini ${ }^{2}$ and A Azwan ${ }^{2}$
}

${ }^{1}$ Department of Animal Breeding and Genetics, Bangladesh Agricultural University, Mymensingh 2202, Bangladesh; ${ }^{2}$ Faculty of Sustainable Agriculture, Universiti Malaysia Sabah, 90509 Sandakan, Sabah, Malaysia

\begin{abstract}
An experiment was conducted at AZ-Zahra Farm, Sandakan, Sabah, Malaysia to investigate the productive and reproductive performance of Saanen dairy goat. Body weight at different ages were collected once while birth weight was collected when does gave birth. On the other hand, milk production of each individual per day was received continuously for three months. The data on reproductive parameters such as length of estrus cycle, duration of estrus period, age at puberty, gestation length, age at first kidding, litter size, birth weight and kid mortality were noted. Descriptive statistics such as number, percentage, mean, standard deviation were performed. T-test was also conducted to know the statistical difference between the groups. Result demonstrated that body weight increases significantly $(p<0.01)$ with the advancement of the age. The highest daily milk yield was found in 2-3 years of age. Dam with multiple kids produced more milk than dam with single kid. Estrus cycle of Saanen goats was found 21 days, the average estrus period duration was 2.75 days, age at puberty was 8.33 months, first kidding age was 14.2 months and gestation period was 150 days on an average. With the increase of the age of dam litter size increased. Meanwhile average birth weight increased as age of dam increased from $2.85 \mathrm{~kg}$ in 1 year to $3.26 \mathrm{~kg}$ in 3 years. Male kids born heavier than females $(3.23 \pm 0.62$ vs. $2.75 \pm 0.58 \mathrm{~kg})$ and single kids were heavier than twin kids $(3.07 \pm 0.66$ kgvs2.70 $\pm 0.28 \mathrm{~kg})$. Low mortality rate of kids was recorded in this study $(6.4 \%)$. It can be concluded that the overall productive and reproductive performances of Saanen goat at AZ-Zahra farm were within the acceptable level and the variation recorded in different parameters is very much usual.
\end{abstract}

Key words: dairy goat, body weight, milk yield, reproductive performance

Bangladesh Animal Husbandry Association. All rights reserved.

Bang. J. Anim. Sci. 2018. 47 (1):1-12

\section{Introduction}

Livestock production in Malaysia is insufficient to meet the domestic demand because of the increase population and consumption. For example, Malaysia produces 51,000 metric tons (MT) of beef, while the demand was more than 201,000 MT in 2013. The demand for mutton is around $28,000 \mathrm{MT}$, while the production was only 4,000 MT in the same year (Fadhilah, 2015). On the other hand, the production of poultry, swine and eggs has exceeded the self-sufficiency. Harsh environmental condition with high temperatures and humidity, as well as quality and supply of feeds is not consistent in Malaysia which are the challenges especially in producing ruminants. Therefore, to increase the local production and to reduce the dependency on importation of beef, lamb and milk, it is necessary to emphasize ruminant production. In developing countries, particularly in Asia, goat plays an important role in the rural economy (Khandoker et al., 2016).
Goat production is regarded as a feasible means to improve the income and nutrition of rural communities and to bring these communities into commercial marketing systems (Braker et al., 2002). Goat production in Malaysia, especially in the state of Sabah is aiming to produce animal protein-based meat and dairy. Small farmers prefer to rear goat as they are easy to handle and less expensive compared to other ruminants. Even though goat farming are practiced just only in small scales but they could gain profitable production in every single goat product produced that are contribute to substantial income to the farmers (Husain et al., 1996). Goats are important for both commercial and subsistent farming systems in Malaysia. Commercial farmer's rear goats primarily for meat production and subsistent farmers use them as a source of meat and milk, as well as cash for other expenses (Casey and Van Niekerk, 1988). There has been an increasing demand for goat meat and their products in Malaysia as there have no religious choice of goat meat. Moreover, consumers' has

*Corresponding author: yahiakhabg@bau.edu.bd 


\section{Performances of Sannen goat in Malaysia}

begun to realize the good quality of goat meat and milk compared to other meat and milk and their products. Goat meat supply precious animal proteins and contains less fat compared to other meat and milk and their products. While the goat milk has a complete dietary supplement which has certain unique characteristics and is most like human milk composition (Harlan, 1990). Besides, as drink goat milk is also used in producing cosmetic products such as soap, shampoo and others. Goat milk is richer in some important nutrients like vitamin A, niacin, choline and inositol than that of cow milk (Harlan, 1990).

In Malaysia, dairy goat production is a small entity in the livestock sector and there is no local dairy goat breed. Since 1950, the interest in dairy goat farming was started by utilizing imported breeds such as Saanen, Anglo Nubian, British Alpine and Toggenburg. The common breeds that are reared especially in Sabah are Saanen, Alpine, and Toggenburg (DVS, 2006). In addition to the production of meat, dairy goat production is also one of the alternatives that are suitable for many small scale or part-time livestock operation. Dairy goat production under smallholder production system has been promoted in developing countries in order to increase consumption of animal protein and raise income of rural poor people through sales of milk, milk products, live animals and manure (FAOSTAT, 2010). Nowadays, there are some dairy goat producers that have been successful in pasteurizing goat milk and some others have ventured into the processing of dairy products for retail distribution, especially cheese and yogurt. The increased efficiency of goats depends on the increased ratio of output (lifetime production) and input (labour, feed, and management). The productive potentiality depends on the productive efficiency of goat from measurement and expression of milk production and body weight. Body weight is an important economic factor which influences the growth and production pattern of any goat enterprise and has more influence mainly on the growth behaviour of kids (McGregor 1984). In many parts of the tropics the traditional goat production system is characterized by random mating, mating of does at early age, high mortality rates, low body weights, low growth rates of kids and poor reproductive efficiency of does (Sebei et al., 1994; Chikagwa-Malunga and Banda, 2006; Kosgey et al., 2006).
Reproductive performance is one of the main determinants of productivity in dairy goat. Reproductive efficiency can be measured and expressed as the service per conception, conception rate, litter size, gestation length, nonreturn rate, age at puberty, age at first kidding, birth types, parity of dam, birth weight and mortality rate. Birth weight and body weight of goat are considered as important traits because there is a positive correlation between birth weight and growth rate, age at maturity and mature body weight (Banerjee, 1989), which influence the future productive and reproductive performance of the animal. A large number of Saanen goats have been imported to this country because of their adaptability and performance (DVS, 2006). This breed can be found in Sabah especially Sandakan area which is being raised in rural areas and also at government livestock farms. It is essential to compile the basic productive and reproductive parameters of dairy goat for documentation and further improvement. Therefore, the objective of this study is to investigate the productive and reproductive parameters of Saanen goat under village system in Sandakan, Sabah, Malaysia.

\section{Materials and Methods}

The study was conducted at AZ-Zahra Farm which is situated at village Sebait Padas Street, Sandakan, Sabah, Malaysia. AZ-Zahra farm is located in Sandakan district at $5058^{\prime} \mathrm{N}$ and 118001 'E. Sandakan is on Sabah's east coast and has a tropical rainforest climate without dry and cold season. Malaysia experiences climate typical of the moist seasonal tropics, with an average annual temperature of $27^{\circ} \mathrm{C}$ and average annual precipitation of $2849 \mathrm{~mm}$ per year (Walsh et al., 2011). Generally there are two distinct seasons in Sabah: the dry and the rainy/wet season. The wetter period occurs during the North East Monsoon from October to February and the drier season during the South West Monsoon from March to September but often there is no sharp division between two seasons.

The main economic activities in Sandakan district are crop and livestock production. The main crop is the oil palm and livestock species kept in this area includes dairy and indigenous Katjang goat, cattle, pigs, chickens and ducks. AZ-Zahra Farm raised goat under intensive husbandry system and received full cares by the workers. In this farm they have about 100 Saanen goats and also there have few other breeds like Alpine and 
Toggenburg. Total of 80 females and 25 males of Saanen goats were randomly chosen for this study. The selection was mostly based on the basis of body structure and conformation. The recording system of this farm is very poor and not practicing any marking of the goat. As a result before starting the work, all the goats were individually ear tagged. The age of the goat was determined mostly by dentition and in some cases from the record. The goats in this farm were managed under intensive husbandry system and usually they were fed with concentrate mixture and palm leaves. The concentrate mixture formulated with brans and soybean husk. Throughout this study the nutrition of the goat remained almost uniform.

\section{Data collection}

The data on productive and reproductive parameters of individual goat were recorded from June 2016 to November 2016.

\section{Productive parameters}

Two types of productive parameters such as body weight and milk production were taken.. Body weight was taken during early morning in empty stomach by using the weighing scale. On the other hand, the information of milk production $(\mathrm{ml})$ of each goat was collected every day for three months started from August until October 2016. Milking was performed at 7.00 AM by hand milking. The does with kids were separated for a night before milking in the next morning and during milking, initially the kids were allowed a short period for sucking to initiate milking. The kid were separated from their dams usually at 4.00 PM and usually milking started at 7.00 AM on the next day to obtain the daily milk yield.

\section{Reproductive parameters}

Reproductive parameters such as length of estrous cycle (days), duration of estrus period (days), age at puberty (days), birth weight of kids (kg), gestation length (days), age at first kidding (days), litter size (number) were taken in this study. Moreover, kid mortality rate (\%) was taken in considered to monitor the herd health status of the farm.

\section{Length of estrous cycle}

Estrous cycle was calculated as the period elapsed between two successive estrus. Repeat heat in the successive cycle due to missing of conceive was recorded and the days between two cycles considered as the length of estrous cycle.

\section{Duration of estrous period}

It is the standing heat for the does and most important time to allow them to mate with buck or performing artificial insemination (AI). In does it was monitored by the activities of mounting, frequent switching of tail, bleating, reddened vulva, vaginal discharge (which causes the tail hairs to stick together), and occasional "riding" by other does. These sorts of activities were monitored closely and recorded as the sign of standing heat in Saanen does during estrus in the present study.

\section{Age at puberty}

Age at puberty is the time when the female goat showing first sign of heat in her life. Does typically reach puberty at about six months of age, although there are some will become fertile sooner. This parameter was evaluated by paying close attention onto the female behavioural towards mating. If the female is mounted then getting pregnant after a few month, so that the age at first estrus considered as the age at puberty.

\section{Birth weight of kids}

The birth weights of kids were taken in kilogram within 6 hours after birth.

\section{Gestation length}

The length of gestation was identified by monitoring the doe from the first successful service until the day doe deliver the kid (s).

\section{Age at first kidding}

Age at first kidding (months) is the age of the doe at giving birth their 1st kid (s).

\section{Litter size}

The data of litter size was obtained by calculating the number of kid (s) per birth. Usually the litter size are single, twin or triplets.

\section{Pre-weaning kid mortality}

To know the overall herd health status of the farm, kid mortality rate was also calculated in this study. The number of kid from viable pregnancy that unable to survive was observed in each birth and the following days after birth and the mortality rate was calculated by using following formula.

Kid mortality rate $(\%)=\frac{\text { Number of kids died before weaning }}{\text { Total number of kids born }} \times 100 \%$ 


\section{Performances of Sannen goat in Malaysia}

\section{Statistical analyses}

The data collected for this study were analysed in accordance with the research objectives. Most of the cases descriptive statistics such as number, percentage distribution, mean, standard deviation were calculated by using Excel 2013. Student's ttest was also performed by using Excel 2013 to know the statistical difference between the groups.

\section{Results}

\section{Body weight of Saanen goat at different ages}

A total of 80 females and 25 males of different ages were considered for this study. Table 1 shows the result of mean of body weight of female goats differed significantly $(p<0.01)$ among the age groups. Highest mean of body weight of female goats were found at 2-3 years old with $36.44 \pm 8.43 \mathrm{~kg}$ (Table 1). Thus, there are no differences among body weight in early age of goat which from birth to weaning.

Table 1 further shows the mean body weight of male goats at different age groups from birth to 2 years of old. The mean body weight of male goats differed significantly $(p<0.01)$ among the age groups. The highest body weight of male goats were found at 1 to 2 years with $32.86 \pm 7.89 \mathrm{~kg}$.

\section{Milk production}

Milk yield of individual doe depends on stage of lactation (Table 2). The height milk yield was observed in October $(784.58 \pm 632.68 \mathrm{ml})$, followed by September $(720.09 \pm 508.32 \mathrm{ml}$ ) and the difference not reached in significant level. On the other hand, significantly lowest $(p<0.05)$ milk yield was recorded in the month of August $(396.24 \pm 200.29 \mathrm{ml})$. Daily milk yield of Saanen goat further compared in different age groups and the result summarized in Figure 1 . In the months of August, September and October significantly height $(p<0.05)$ milk yield was recorded in 2-3 years age group of goats (456.89 $\pm 243.86,977.14 \pm 582.94$ and $996.63 \pm$ 619.31 , respectively) than that of other three age groups with little exception. In 3-4 years and 4-5 years also recoded significantly $(p<0.05)$ elevated milk yield than that of 1-2 year age group of Saanen goat (Figure 1). Milk yield was also compared between single kidding to twin kidding dams and found that milk production of Saanen goat was seriously affected by the birth type (data not shown). On an average, twin kidded dams produces higher milk (1428.6 \pm $956.23 \mathrm{ml} / \mathrm{d} / \mathrm{got}$ ) than that of single kidded dams $(636.00 \pm 340.91 \mathrm{ml} / \mathrm{d} / \mathrm{goat})$ and the values also differed significantly $(p<0.05)$.

Table 1. Body weight mean of male and female Saanen goat at different ages

\begin{tabular}{ccc}
\hline Age & Body weight & in kg (mean \pm SD) \\
\cline { 2 - 3 } groups & Male & Female \\
\hline Birth & $3.07 \pm 0.58^{\mathrm{a}}$ & $2.75 \pm 0.62^{\mathrm{a}}$ \\
& $(8)$ & $(6)$ \\
15 & $4.10 \pm 0.57^{\mathrm{a}}$ & $3.45 \pm 0.07^{\mathrm{a}}$ \\
days & $(2)$ & $(4)$ \\
1 & $5.46 \pm 0.22^{\mathrm{a}}$ & $5.16 \pm 0.42^{\mathrm{a}}$ \\
month & $(5)$ & $(13)$ \\
2 & $7.03 \pm 0.64^{\mathrm{a}}$ & $7.09 \pm 0.77^{\mathrm{a}}$ \\
months & $(3)$ & $(5)$ \\
10 & $25.53 \pm 0.13^{\mathrm{b}}$ & $18.97 \pm 8.06^{\mathrm{b}}$ \\
months & $(2)$ & $(4)$ \\
$1-2$ & $32.86 \pm 7.89^{\mathrm{c}}$ & $30.13 \pm 9.92^{\mathrm{c}}$ \\
years & $(5)$ & $(10)$ \\
$>2-3$ & - & $36.44 \pm 8.43^{\mathrm{cd}}$ \\
years & & $(19)$ \\
$>3-4$ & - & $32.46 \pm 6.96^{\mathrm{c}}$ \\
years & & $(15)$ \\
$>4-5$ & - & $40.24 \pm 3.01^{\mathrm{d}}$ \\
years & & $(4)$ \\
\hline
\end{tabular}

$a, b, c, d$, Means with different superscripts within the same column differed significantly $(p<0.01)$. ( ) indicates the number of observation

Table 2. Descriptive statistics for daily milk yield $(\mathrm{ml})$ of Saanen goat

\begin{tabular}{cccc}
\hline Month & $\begin{array}{c}\text { Minimum } \\
\text { (ml/d/ } \\
\text { goat) }\end{array}$ & $\begin{array}{c}\text { Maximum } \\
\text { (ml/d/ } \\
\text { goat) }\end{array}$ & $\begin{array}{c}\text { Mean } \text { ( SD } \\
\text { (ml/d/goat) }\end{array}$ \\
\hline $\begin{array}{c}\text { August } \\
\text { (25) }\end{array}$ & 50 & 1170 & $396.24 \pm 200.29^{\mathrm{a}}$ \\
$\begin{array}{c}\text { September } \\
\text { (32) }\end{array}$ & 100 & 2200 & $720.09 \pm 508.32^{\mathrm{b}}$ \\
$\begin{array}{c}\text { October } \\
(31)\end{array}$ & 50 & 2580 & $784.58 \pm 632.68^{\mathrm{b}}$ \\
\hline
\end{tabular}

a, b, Means with different superscripts within the column differ significant $(p<0.05)$. () indicates the number of observation 


\section{Reproductive performances of Saanen female goat}

The reproductive parameter of female goats at AZ-Zahra Farm in Sandakan is summarized in Table 3. The length of estrous cycle of Saanen goats was found 21 days on an average, while their estrus period duration was recorded as 2.75 days. The age at puberty of Saanen goats was recorded 8.33 months, first kidding age was found to be 14.2 months and gestation period was 150 days on average (Table 3 ).

The result of litter size (single and twin) in percentage and the average birth weight in two groups of litter sizes and in two either sexes are presented in Table 4. Irrespective of age of the dam, $90 \%$ of the birth was recorded as single and only $10 \%$ was recorded as twin. The higher birth weight of the kid was recorded in single birth $(3.07 \pm 0.66 \mathrm{~kg})$ than that of twin birth $(2.70 \pm 0.28 \mathrm{~kg})$. On the other hand, heavier average birth weight was recorded in male kid $(3.23 \pm 0.62 \mathrm{~kg})$ than that of female kid $(2.75 \pm 0.58 \mathrm{~kg})$.

\section{Discussion}

\section{Body weight at different ages}

For animal selection body weight is one of the important parameter (Cam et al., 2010). Live weight is one of the important factors in determining potential milk production and several characteristics of the farm animals especially the ones having economic importance. Teke et al. (2011) reported that the average live weight of Saanen kids on birth was 3.29, which was higher than the value found in present study. Birth weight of kids was found to be negatively correlated with survival and positively correlated with subsequent weight gain (Sebei et al., 1994). However, Merlos-Brito et al. (2008) found that the offspring of Boer goat born from single births had higher weaning weight $(15.1 \mathrm{~kg})$ than those born from twin births $(13.4 \mathrm{~kg})$. They explained this phenomenon by competition with two teats through udder milk, compared with those of one offspring. The sex of kid also can affect birth weight, weaning and post-weaning gains (Andries, 2013).

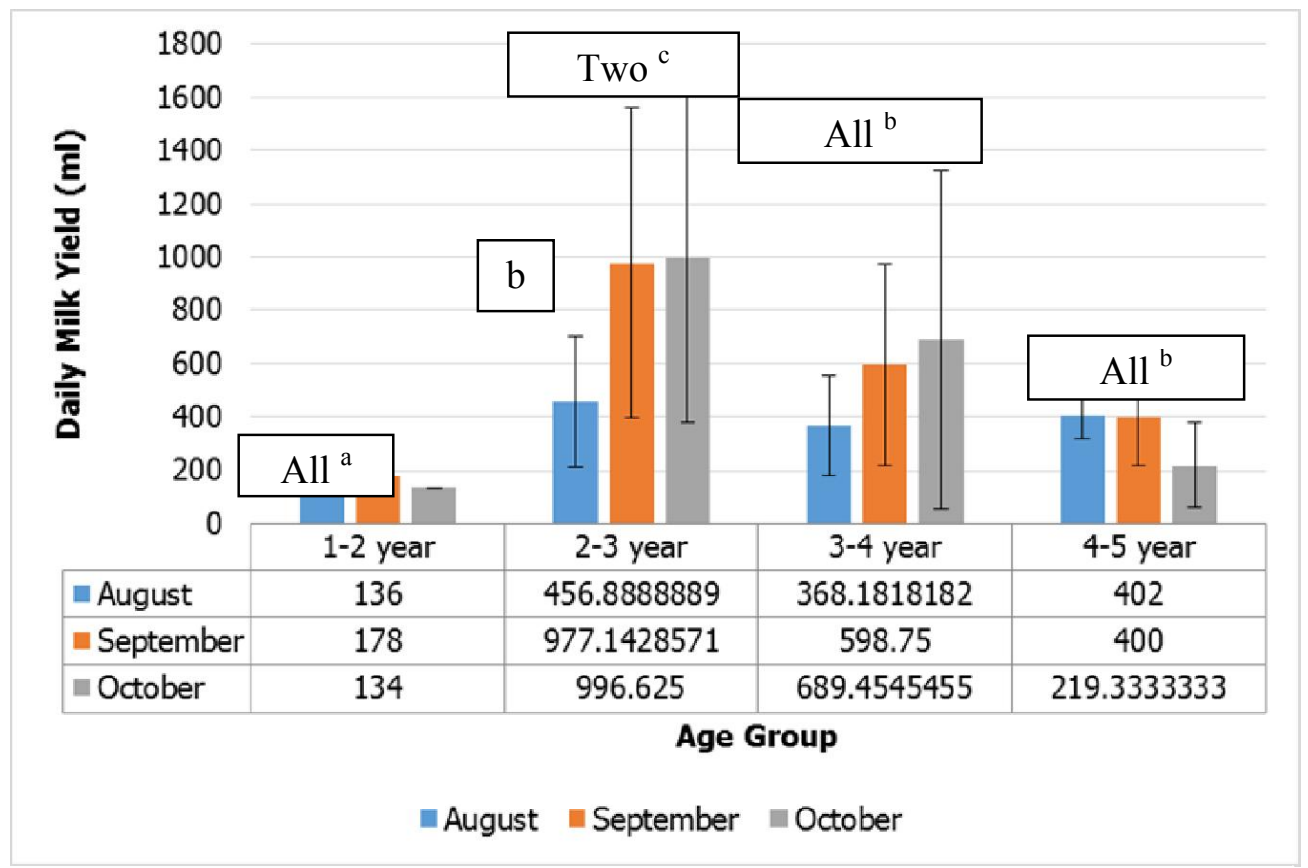

Figure 1. Daily milk yield of Saanen goat at different ages in three months $\left({ }^{a}, b, c\right.$, Means with different superscripts differed significantly $(p<0.05)$ from each other) 


\section{Performances of Sannen goat in Malaysia}

Table 1 clearly indicates that body weight increases proportionally with the advancement of age. Further, maximum body weight gain was observed from 10 months might be due to natural increase of dry matter intake after reaching in puberty. In comparison between male and female goats, males of Saanen goat showed higher body weight than their counter part females at different stages of ages. Usually the growth rate of male is higher than that of the female (Pesmen and Yardimci, 2008) which supports the findings of current study.

\section{Milk production}

The average milk yield per day in the present study found lower $(784.58 \mathrm{ml})$ compared to the previous study of Kurwijila et al. (1985) in Saanen goat. This might be due to the different feeding strategies. Daily average milk production in August showed less than that of the following months of September and October, this might be due to supplementation of feed. In September and October, this farm started fed with concentrate supplementation to the milking goat. This result is in agreement with Min et al. (2005) who reported an increase in milk production with increase in the level of supplementation. Furthermore Lefrileux et al. (2012) reported that higher milk production by does supplemented above $800 \mathrm{~g} /$ day with concentrates.

In present study, the increase of milk yield with the advancement of doe's age might be due to the increase in body weight which is related to the increase in udder and gastrointestinal volume both of which are associated with the increase of feed intake (Ketto et al., 2014). This result further supported by Muller (2005) and Ciappesoni et al (2004). They reported that does which kidded at a younger age had lower milk yield compared to those with higher age.

Milk yield of goat was also affected by some other factors such as breed, age of goat at kidding, season of kidding and parity of the dam (Prakash et al., 1971). In this study, higher milk yield per goat $(1428.6 \mathrm{ml})$ was also recorded of the doe of twin kids (data not shown). This result reveals that twin kidded dams produce higher amount of milk. Similar results were also reported in Zaraibi goats in Egypt (Hamed et al., 2009). Mourad (1992) reported that litter size affected milk yield of goats until weaning. Furthermore, Bernacka and Siminska (2009) also reported that does with multiple kids had higher milk yield compared to does that kidded single kids. Ciappesoni et al (2004) also observed significantly higher average daily milk yield by does that kidded twins compared to the does kidding singles (3.49 vs 3.59 litres/day). Well-developed mammary glands during pregnancy and the sucking of multiple kids induces more milk synthesis from the udder could be the reasons in higher milk yield in does kidding multiple kids.

\section{Reproductive performance of Saanen goat}

Reproductive performance of female goat is determined by various parameters including length of estrus cycle, duration of estrus period, age at puberty, birth weight of kids, gestation length, age at first kidding, litter size, and the survivability of the offspring.

\section{Length of estrus cycle}

It is characterized by appearance of first estrus to coming in next estrus (Pinede and Dooley, 2003). The length of estrus cycle was documented and reported which ranged in between 19-24 days in various breeds of goat (Bukar et al., 2012; Khanum et al., 2007; Zarkawi and Soukouti, 2001).

In this study, the mean length of estrus cycle was recorded $21.0 \pm 4.24$ days in Saanen goats. This is consistent with the value found by Kaymakci and Askin (1997) for milk goats (21 days) but it is higher than the other authors (Stuwe and Grodinsky, 1987; Lopes Junior et al., 2001; Lehloenya et al., 2005; Moaeen-udDin et al., 2008). Arthur et al., (1998) and Hafez and Hafez (2000) also reported that in tropical zone where variation in day length is less, goats tend to breed throughout the year and the does are polyoestrous with interoestrous interval of 20-21 days.

Table 3. Different reproduction parameters of Saanen female goats at A-Z-Zahra farm in Sandakan

\begin{tabular}{lcc}
\hline Parameters & $\begin{array}{l}\text { No. of } \\
\text { observations }\end{array}$ & Mean \pm SD \\
\hline $\begin{array}{l}\text { Length of estrus } \\
\text { cycle (days) }\end{array}$ & 2 & $21.0 \pm 4.24$ \\
$\begin{array}{l}\text { Duration of estrus } \\
\text { (days) }\end{array}$ & 2 & $2.75 \pm 0.35$ \\
$\begin{array}{l}\text { Age at puberty } \\
\text { (months) }\end{array}$ & 3 & $8.33 \pm 1.53$ \\
$\begin{array}{l}\text { Gestation length } \\
\text { (days) }\end{array}$ & 2 & $150.0 \pm 7.77$ \\
$\begin{array}{l}\text { Age at first kidding } \\
\text { (months) }\end{array}$ & 2 & $14.2 \pm 2.40$ \\
\hline
\end{tabular}




\section{Duration of estrus period}

Estrus period duration is known as the onset of appearance of estrus symptoms to disappearance of estrus symptoms in the same estrus and in same animal. Doe showed typical characteristics of sexual behaviour and takes interest in buck during estrus. This change in physical behaviour of doe is caused to the hormonal influence on reproductive system. The dominant hormones are estrogen in estrus produced by mature follicles and progesterone by developed corpus luteum of cycle in goat (Pinede and Dooley, 2003).

The mean duration of the estrus period was found as $2.75 \pm 0.35$ day during the present investigation in Saanen goat. The findings of the current study were in accordance with the results reported by Bukar et al. (2012) and Greyling (2010). They reported the ranges of duration of estrus24-56 hours (1-3 days) and 10-36 hours (1-2 days), respectively in Boer goat does. In some breeds it varies from 22 to 60 hours (1-3 days) (Bukar et al., 2012).

\section{Age at puberty}

The point of sexual development at which the animal becomes capable for reproduction and starts sexual activity is known as puberty. Sexual development in the goat is defined as a process of gradual maturation and interaction between the brain, pituitary and gonads. The direct cause of sexual maturation at puberty is a rise in the output of the pituitary hormones, leading to an increase in size and activity of the gonads (Hunter 1980; Cupps, 1991). Puberty in both buckling and doelings are controlled by sexual hormones which testosterone in the buckling while estrogen in doelings. It is the time when estrus is shown for first time followed by characteristic ovarian activity and ovulation in female and ejaculation of sperm in male (Snyman, 2010; Haliu et al., 2006; Greyling, 2000). At this stage often goats are not fully sexually competent for reproduction (Snyman, 2010). Puberty is generally considered to be related more to growth and body weight rather than age in tropical goats (Bushara and Abu-Nikhaila, 2012; Delgadillo et al., 2007; Sodiq et al., 2002). Generally breeding may be delayed until the animal has attained $60-70 \%$ of its adult body weight (Devendra, 2007; Greyling, 2010).

Age at puberty was reported in earlier studies 180-540 days (6-18 months) in different breeds of goats under different ecological and management conditions (Dereje et al., 2015; Baloch, 2014; Zarkawi and Al-Saker, 2013). Generally, male Saanen goats reach puberty at the age between 4-8 months and the female Saanen goat is between 7-10 months. The mean age at puberty was recorded in the present study as 8.33 months in Saanen female goat. The results of present investigations a bit higher than those reported by Zeshamani et al. (2007), they reported that the Saanen goat reach puberty at around 7 months. Most of the goat breeds attain puberty approximately at eight months of age (Delgadillo et al., 2007; Chemineau et al., 2004) and usually bred at 710 months of age (Song et al., 2003).

Furthermore, the puberty attainment is highly variable and is not only under the influence of age, but also affected by factors such as breed, nutrition, management, environmental temperature, photoperiod and body weight (Adam and Robinson, 1994; Delgadillo and Malpaux, 1996). Generally, the live weight at which puberty is generally attained is between 40 and $60 \%$ of the adult body weight and the age at puberty ranges between 5 and 18 months (Chemineau et al., 1991). The live body weight of Saanen goat at the age of puberty in the present study ranges between 25-30 kg and similar to reported by Amoah and Bryant (1984). They reported that Saanen kids born in March and April reached puberty at 30 $\mathrm{kg}$. The relationship of age and body weight to onset of puberty and attainment of sexual maturity is required for improvement of reproductive performance. The reason of delayed age at puberty may be cause by genetic factor, climate and management practices at the farm which need to be improved.

\section{Gestation length}

Gestation length of Saanen goat in this study was found as $150 \pm 7.77$ days. The gestation length is known to be around 150 days (Hafez and Hafez, 2000 and Wang et al., 1991). As compared to the finding of other author (Moaeen-ud-Din et al., 2008), there was no consistent change in the mean gestation length in Saanen goats of this study. There are various physiological and environmental factors have been reported to affect the gestation length in goat. It may be affected by factors like season, year, sire, litter size, kidding age of dam, parity, birth weight of the kid, weight of dam at mating, generation and kidding intervals reported by Chowdhury et al. (2002). While Amoah and Bryant (1983) observed that the gestation length was affected by litter size and 


\section{Performances of Sannen goat in Malaysia}

sex of kid. However, these factors did not affect in length of gestation in Saanen goat as evident in this study.

\section{Age at first kidding}

The age at first kidding is expressed as the age when does produce offspring for the first time. Age at first kidding is an essential indicator in determining of sexual maturity and life time productivity in does, the earlier the doe starts to kid it will produce more kids in life time and longer would be the productive life time period (Deribe and Taye, 2014).

In present study, the mean age at first kidding was recorded as $14.2 \pm 2.40$ months in Saanen goat. The age at first kidding was reported in between 387-693 days among the various production patterns and goat breeds (Zarkawi and Abu-Saker, 2013; Lund, 2006; Ali, 2006; Sodiq, 2002; Song et al., 2003; Wilson, 1988).

\section{Litter Size}

Litter size is defined as a total number of born kids per kidding and per goat. The litter size at birth is an essential trait for selection of goats to produce next generation and increase of milk production. There are numerous factors that influence the litter size in goats. Amoah and Gelaye (1990) established that litter size was under significant influence of goat age and parity, whereas Awemu et al (1999) stated parity, year and season as factors of importance for goat litter size.

Table 4. Average litter size and birth weight of Saanen goat kids

\begin{tabular}{|c|c|c|}
\hline Parameters & Single* & Twin* \\
\hline Litter size (\%) & 90.0 & 10.0 \\
\hline $\begin{array}{l}\text { Average birth } \\
\text { weight on the } \\
\text { basis of birth } \\
\text { type }(\mathrm{kg})\end{array}$ & $\begin{array}{c}3.07 \pm 0.66 \\
(12)\end{array}$ & $\begin{array}{c}2.70 \pm 0.28 \\
\text { (1) }\end{array}$ \\
\hline $\begin{array}{l}\text { Average birth } \\
\text { weight on the } \\
\text { basis of sex }(\mathrm{kg})\end{array}$ & $\begin{array}{c}\text { Male } \\
3.23 \pm 0.62 \\
(9)\end{array}$ & $\begin{array}{c}\text { Female } \\
2.75 \pm 0.58 \\
(5)\end{array}$ \\
\hline
\end{tabular}

*Within brackets represents the number of observation

The litter size in this study ranged from single to twin with the percentages of 90 and 10, respectively and it is lower than the values found by Dorbinc et al. (1999), Taskin et al. (2003). Higher age, body weight, parity and previous litter size have positive influence on multiple births in Saanen goats. These findings are in general agreement with the previous reports on does (Mellado et al., 1991).

\section{Birth weight of kids}

Birth weight as an early measurable trait is of great interest because of its positive genetic correlation with further live weights (Madeli and Patro 1984; Roy et al., 1989). Mean birth weight of kids reported heavier in single birth $(3.07 \pm 0.66 \mathrm{~kg})$ than that of the twins $(2.70 \pm 0.28 \mathrm{~kg})$. This is in agreement with Gebrulul et al., (1994). Twins or triplets tended to have lower birth weights. Curtis (1969) concluded that animals with low birth weights had lower energy reserved and were therefore less able to withstand harsh environments. Also, poor milk yield in dams, she may be unable to provide adequate nutrition for twins. Bucklings were significantly heavier $(3.23 \mathrm{~kg})$ than doelings $(2.75 \mathrm{~kg})$ at birth and this result is similar to Ugur et al. (2004).

In addition, higher birth weight was recorded in male $(3.23 \pm 0.62 \mathrm{~kg})$ than that of the female $(2.75 \pm 0.58)$ in the present study is very usual and supported by the previous study of Wenzhbong et al. (2005) and Djemali et al. (1994.

\section{Mortality rate}

Mortality rate of kids from birth to weaning is one of the crucial elements in the economic process of goat raising programs (Sebei et al., 1994; Singh et al., 1990). This rate was reported to range from 32 to $40 \%$ in different goat breeds (Rattner et al., 1994; Chawla et al., 1982; Donkin and Boyazoglu 2004). Environmental factors, other than diseases, were reported to have a significant effect on mortality rate (Miah et al., 2002).

The mean of mortality rate from birth to weaning obtained in this study $6.4 \%$ which is lower than $11.3 \%$ reported by Ikwugbu and Ofadile (2008) for similar weaning age using West African Dwarf goats. Kid mortality usually affected by some environmental factors and better management might reduce it.

\section{Conclusion}

Results of this study reveals that the overall productive and reproductive performance of Saanen goats at AZ-Zahra farm in Sandakan Sabah, Malaysia are within the acceptable level and the variation recorded in different parameters is very much practical. 


\section{Acknowledgement}

The research is supported by a research grant from Universiti Malaysia sabah (UMS), Malaysia. The authors are very much grateful to Cikgu Raiha Ab Rahman the owner of AZ-Zahra goat Farm for allowing us to do research in her farm.

\section{References}

Adam CL and JJ Robinson (1994).The role of nutrition and photoperiod in the timing of puberty. Proceeding of Nutritional Society 53: 89-102.

Ali A (2006). Genetic evaluation of beetal goats for performance traits in Pakistan. A PhD thesis. University of Agriculture, Faisalabad.

Amoah EA and S Gelaye (1990). Reproductive performance of female goats in South Pacific countries. Small Ruminant Research 3:257267.

Amoah EA and MJ Bryant (1983). Gestation period, litter size and birth weight in the goat. Animal Production 36: 105-110.

Amoah EA and MJ Bryant (1984). A note on the effect of contact with male goats on occurrence of puberty on female goat kids. Animal Production 38:141-144.

Andries KM (2013). Growth and performance of meat goat kids from two seasons of birth in Kentucky. Sheep Goat Research Journal 28:16-20.

Arthur GH, DE Noakes, R Harold and TJ Parkinson (1998). Veterinary Reproduction and Obstetrics. 7th edition. WB Saunders Company limited, London.

Awemu EM, LN Nwakolar and BY Abubakar (1999). Environmental influences on preweaning mortality and reproductive performance of Red Sakoto does. Small Ruminant Research 34:161-165.

Baloch SN (2014). Study on performance analysis of Kamohri goat flock under semi intensive management at government Bhagnari cattle farm Usta Muhammad Baluchistan. Master of Science Thesis, Sindh Agriculture University Tandojam.

Banerjee GC (1989). A text book of Animal Husbandry. Seventh edition, Oxford and IBH publishing Co. India.

Bernacka $H$ and L Siminska (2009). The effects of age and pregnancy type in the coloured enhanced goats on productivity and composition of milk. Journal of Central European Agriculture 10:67-72.
Braker MJE, HM Udo and EC Webb (2002). Impacts of intervention objectives in goat production within subsistence farming. South African Journal of Animal Science 32:185-191.

Bukar MM, R Yusuf, AW Haroon, GK Dhaliwal, MAG Khan and MA Omar (2012). Estrus response and follicular development in Boer does synchronized with flagstone acetate and PGF2 $\alpha$ or their combination. Tropical Animal Health Production 44:1505-1511.

Bushara I and MMAA Abu-Nikhaila (2012). Productivity performance of Taggar female kid under grazing condition. Journal of Animal Production Advances 2:74-79.

Cam MA, M Olfaz and E Soydan (2010). Body measurements reflect body weights and carcass yields in Karayaka sheep. Asian Journal of Animal Veterinary Advances 5:120127.

Casey NH and WA Van Niekerk (1988). The Boer goat. Origin, adaptability, performance testing, reproduction and milk production. Small Ruminant Research 1:291-302.

Chawla DS, DS Bhatnagar and RR Mishra (1982). Factors affecting kid mortality in dairy goats. Indian journal of Animal Science 52:166-171.

Chemineau PA, Y Daveau, G Cognie and D Chesneau (2004). Seasonal ovulatory activity exists in tropical creole female goats and black belly ewes' subjected to temperate photoperiod. BMC Physiology 4:12.

Chemineau P, Y Cagnie, Y Gue'rin, P Orgeur and JC Vallet (1991). Training manual on artificial insemination in sheep and goat. FAO. Rome: 222.

Chikagwa-Malunga, SK and JW Banda (2006). Productivity and survivability of goats in smallholder crop/livestock farming systems in Malawi. Livestock Research and Rural Development. 18.

Chowdhury SA, MSA Bhuiyan and S Faruque (2002). Rearing Black Bengal does. AsianAustralia Journal of Animal Science 15: 477488.

Ciappesoni G, J Pribyl, M Milersk and $V$ Mares (2004). Factors affecting goat milk yield and its composition. Czech Journal of Animal Science 49:465-473.

Cupps PT (1991). Reproduction in domestic animals. Fourth Ed.Aca Press Inc. San Diego, New York, Boston.

Curtis HJ (1969). Animal growth and nutrition. Lea and Fibger, Philadelphia, USA. pp.165-174.

Delgadillo JA, MA Santiago-Miramontes and E Carrillo (2007). Season of birth modifies 


\section{Performances of Sannen goat in Malaysia}

puberty in female and male goats raised under sub-tropical conditions. Journal of Animal Production 1:858-864.

Delgadillo JA and B Malpaux (1996). Reproduction of goats in the Tropics and Subtropics. Sixth international Conference on goats, 2, 785793.International Academy Publisher, Beijng, China.

DVS, Department of Veterinary Services (2006). First report on the state of the world's animal genetic resources: Animal Genetic Resources in Malaysia. Malaysia.

Dereje T, U Mengistu, AGetachew and MYoseph. (2015). Perceptions of households on purpose of keeping, trait preference, and production constraints for selected goat types in Ethiopia. Tropical Animal Health Production 46:363-370.

Deribe B and M Taye1 (2014). Reproductive performance of Abergelle goats raised under traditional management systems in Sekota District, Ethiopia. Iran Journal of Applied Animal Science 4:59-63.

Devendra C (2007). Small ruminants in Asia. Contribution to food security, poverty alleviation and opportunities for productivity enhancement. http://www.mekarn.org/procsr.

Djemali M, R Aloulou and M Bensassi (1994). Adjustment factors and genetic and phenotypic parameters for growth traits of Barbarine lambs in Tunisia. Small Ruminant Research 13:41-47.

Donkin EF and P Boyazoglu (2004). Diseases and mortality of goat kids in a South African milk goat herd. South African Journal of Animal Science 34: 220-223.

Dorbinç M, D Kompan and AKomprej (1999). Fertility of sheep and goat in Slovenia. ActaAgraria Komposváriensis 3: 79-90.

Fadhilah HHA (2015). Strategies to strengthen livestock industry in Malaysia. Economics and Social Science Research Center, Malaysian Agriculture Research and Development. Accessed on 29 July 2016. http:// ap.fftc.agnet.org/ ap_db. php Verified on 28 November 2016

FAOSTAT (2010). Food and Agriculture Organization of the United Nations official statistics. http://faostat. fao.org/ faostat/ collections Accessed on 22nd May 2016.

Gebrelul S and LSM Iheanacho (1994). Genetic and nongenetic effects on growth and mortality of Alpine, Nubian and crossbred kids. Small Ruminant Research 13: 169-176.
Greyling JPC (2010). Applied Reproductive Physiology. In: Solaiman.A.G.Ed. Goat Science and Production. First Edition. Iowa, USA: Blackwell Publishing, pp: 139-155.

Greyling, JPC (2000). Reproductive traits in the Boar goat doe. Small Ruminant Research 36: 171-177.

Hafez B and ESE Hafez (2000). Reproduction in farm animals. Seventh edition. Awolters Kuwe company, Phildelphi. USA.

Hailu D, G Miesu, A Nigatu, D Futa and D Gamada (2006). The effect of environment factors on pre-weaning survival rate of Borana and ArsiBale kids. Small Ruminant Research 66:291294.

Hamed A, MM Mabrouk, I Shaat and S Bata (2009). Estimation of genetic parameters and somenon-genetic factors for litter size at birth and weaning and milk yield traits in Zaraibi goats.Egypt Journal of Sheep and Goat Science 4: 55-64.

Harlan HAD (1990). Understanding Dairy Goat Production.http://www.goatworld.com/ articles/ udgp. shtml. Accessed on 28 June 2016.

Hunter RHF (1980). Physiology and Technology of Reproduction in female domestic animals. Academic Press, London, New York.

Husain SS, P Horst and ABMM Islam (1996). Study on the growth performance of Black Bengal goats in different periods. Small Ruminant Research 21:165-171.

Ikwuegbu OA and S Ofadile (2008). Wet season supplementation of West African Dwarf raised under traditional management in the subhumid zone of Nigeria. http://www.fao.org/ Wairdocs/ ILRI/ x5472B/ x5472b0z.html, 2006.

Kaymakçı M and Y Aşkın (1997). KeçiYetiştiriciliği. EgeÜniversitesiZiraatFakültesi, Bornova, Đzmir, p. 294.

Ketto IA, I Massawe and GC Kifaro (2014). Effects of supplementation, birth type, age and stage of lactation on milk yield and composition of Norwegian $x$ Small East African goats in Morogoro, Tanzania.

Khandoker MAMY, M Syafiee and MS Rahman (2016). Morphometric characterization of Katjang goat of Malaysia. Bangladesh Journal of Animal Science 45:17-24.

Khanum SA, M Hussain and R Kausar (2007). Assessment of reproductive parameters in female. Dwarf goat (Capra hircus) on the basis 
of progesterone profiles. Animal Reproduction Science 102:267-275.

Kosgey IS, RL Baker, HMJ Udo, and JAM Van Arendonk (2006). Successes and failures of small ruminant breeding programs in the tropics: a review. Small Ruminant Research 61:13-28.

Kurwijila RL, KK Hansen and R Ryoba (1985). Some experiences on goat milk utilization. In: Improved dairy production from cattle and goats in Tanzania. Occasional paper series B9:54-62.

Lefrileux $Y, P$ Morand-Fehr and A Pommaret (2012). Capacity of milk yielding goats to utilize cultivated pastures. INRA Animal Production 25:277-290.

Lehloenya KC, JPC Greyling and LM Schwalbach (2005). Reproductive performance of South African indigenous goats following oestrous synchronisation and AI. Small Ruminant Research 57:115-120.

Lopes Jr ES, D Rondina, AA Simplício and VJF Freitas (2001). Oestrus behaviour and performance in vivo of Saanen goats raised in northeast of Brazil. Livestock Research for Rural Development 13:1-14.

Lund SK (2006). Study on performance analysis of Dera Din Panah goat. RakhKhairayWali, district Layyah, Punjab. MSc Thesis. Department of Livestock Management, Sindh Agriculture University, Tandojam.

Madeli UC and BN Patro (1984). Heritability and correlations among body weights at different ages in Ganjam goats. Indian Veterinary Journal 61:233-235.

McGrego, BA (1984). Growth, development and carcass composition of goats. A review, goatproduction and research in the tropics. Proceeding of a workshop held at the University of Queensland, Brisbane, Australia, ACAR Proceedings Series No. 7.

Mellado M, RH Foote and E Borrego (1991). Lactational performance, prolificacy and relationship to parity and body weight in crossbred native goats in north Mexico. Small Ruminant Research 6:167-174.

Merlos-Brito MI, RD Martínez-Rojero, G TorresHernández, AA Mastache-Lagunas and J Gallegos-Sánchez (2008). Evaluación de característic as productivas en cabritos Boer $x$ local, Nubia $\times$ local y locales en el trópicoseco de Guerrero, México [Evaluation of productive traits in Boer $x \quad$ local, Nubia $\times$ local and local in the dry tropic of Guerrero, Mexico]. Veterinary México 39:323-333.
Miah G, SS Husain, MA Hoque and DH Baik. (2002). Effect of genetic and non-genetic factors other than disease on kid survivability in goats. Korean Journal of Animal Science and Technology 44:271 278 .

Min BR, SP Hart, T Sahluand LD Satter (2005). The effect of diets on milk production and composition, and on lactation curves in pastured dairy goats. Journal of Dairy Science 88:2604-2615.

Moaeen-ud-Din M, LG Yang, SL Chen, ZR Zhang, JZ Xiao, QY Wen and Dai M. (2008). Reproductive performance of Matou goat under sub-tropical monsoonal climate of Central China. Tropical Animal Health and Production 40:17-23.

Mourad M (1992). Effects of month of kidding, parity and litter size on milk yield of Alpine goats in Egypt. Small Ruminant Research 8: 41-46.

Muller CJC (2005). Genetic parameter estimation and breeding plans for the South Africa dairy goat herd. In: Proceedings of the 7th World Congress on Genetics Applied to Livestock Production, August2005, Montpellier, France, 1:52-55.http:// scholar.sun.ac.za/bitstream/handle/10019.1/1 468/ Muller, \%20C\%20J\%20C.pdf?sequence.

Pesmen G and M Yardimci (2008). Estimating the live weight using some body measurements in Saanen goats. Archive a Zootechnica 11:4, 30-40.

Pineda MH and MP Dooley (2003). Veterinary Endocrinology and Reproduction. McDonalds $5^{\text {th }}$ Ed. Iowa, USA, Iowa State Press. Pp: 597.

Prakash C, RM Acharya and JS Dhillon. (1971). Sources of variation in milk production in Beetal goats. Indian Journal of Animal Science 41: 356-360.

Rattner D, J Riviere and JE Bearman (1994). Factors affecting abortion, stillbirth and kid mortality in he goat and yaez (goat $x$ ibex). Animal Breed 62:8.

Roy R, B Prakash and BU Khan (1989). Genetic and non-genetic sources of variation for growth in Jamnapari kids. Indian Journal of Animal Science 59:874-877.

Sebei PJ, CME McCrindle and EC Webb (1994). Factors influencing weaning percentages of indigenous goats on communal grazing. South African Journal of Animal Science 34:130-133.

Singh DK, HR Mishra and CSP Singh (1990). Genetic and non-genetic factors affecting preweaning survivability in kids. Animal Production 51: 559-564. 


\section{Performances of Sannen goat in Malaysia}

Snyman MA (2010). Factors affecting pre-weaning kid mortality in South African Angora goats. South Africa Journal of Animal Science 40: 54-64.

Sodiq A, A Soeditoand ES Tawfik (2002). Doe productivity of Kacang and Peranakan Etawah goat in Indonesia and factors affecting them. http:/www. Goggle. Com. /search.

Song HB, IK Choi and TG Min. (2003). Reproductive traits in the Korean goat Doe.Jinryang, Kyungsan, Kyungbuk. Pp: 712-714.

Stüwe M and C Grodinsky (1987). Reproductive biology of captive alpine ibex (Capra $i$. ibex). Zoo Biology 6:331-339.

Taşkın T, E Demirören and M Kaymakçı (2003). SaanenveBornovakeçilerindeoğlakveriminin üretkenliğiveetkinliği.EgeÜniversitesiZiraatFak ultieDergisi 40: 33-40.

Teke B, F Akdağ and S Arslan (2011). Some fertility, growth and behavioral traits of Saanen goats rassed on private farm condition. Faculty of Veterinary Medicine. İstanbul Üniversity 37:18.

Ugur F, T Savas, M Dosay, AKarabayir and C Atasoglu (2004). Growth and behavioral traits of Turkish Saanen kids weaned at 45 and 60 days. Small Ruminant Research 52:179-184.
Walsh KJ, A Morbidelli, SN Raymond, DP O'Brien and AM Mandell (2011). Nature 475:206.

Wang J, E Duan, O Huang, Z Hao and $\mathrm{H}$ Wlu (1991). Reproductive Performance in the Saanen goat in China Vienna, Australia; International Atomic Energy Agency 165-176 BBN, 92-0.111091.

Wenzhong L, Z Yuan and Z Zhongxiao (2005). Adjustement for non-genetic effects on body weight and size in Angora goats. Small Ruminant Research 59:25-31.

Wilson RT. (1988). The productivity of Sahel goats and sheep under transhumant management in Northern Burkina Faso. Bulletin of Animal Health and Production in Africa 36:348-355.

Zarkawi M and MB Al-Saker (2013). Determination of certain reproductive and productive parameters in female Mountain (Jabali) and crossbred goats during different age stages. Archivs Zootechica 16:15.

Zarkawi MI and A Soukouti (2001). Serum progesterone levels using radioimmunoassay during estrous cycle of indigenous Damascus does. NewZealand Journal of Agricultural Research 44:165-169.

Zeshamani S, KC Dhara, AK Samanta, R Samanta and SC Majumder (2007). Reproductive performance of goat in Eastern and NorthEastern India. Livestock Research and Rural Development 19:38-42. 